\title{
Hubungan Keterampilan Mengajar Guru Mata Pelajaran PPKn Terhadap Minat Belajar Peserta Didik
}

\author{
Zsekhar Mehta Pradipta Yudah, ${ }^{a, 1}$ Trisna Sukmayadi ${ }^{b, 2^{*}}$ \\ a, b Program Studi PPKn, Universitas Ahmad Dahlan, Yogyakarta \\ ${ }^{1}$ zsekhar1400009058@webmail.uad.ac.id ${ }^{2}$ trisnasukmayadi@ppkn.uad.ac.id \\ * korespondensi
}

\begin{abstract}
ABSTRAK
Guru memiliki peranan yang sangat penting dalam proses pembelajaran di sekolah. Karena itu, maka guru dituntut untuk memiliki keterampilan mengajar yang inovatif dan kreatif agar dapat meningkatkan minat belajar peserta didik. Tujuan penelitian ini adalah untuk mendeskripsikan pengaruh keterampilan mengajar guru mata pelajaran PPKn terhadap minat belajar peserta didik di SMPN 2 Kasihan Bantul. Penelitian ini termasuk ke dalam penelitian kuantitatif. Keberhasilan penelitian ini dilihat dari ada tidaknya pengaruh keterampilan mengajar guru mata pelajaran PPKn terhadap minat belajar peserta didik SMPN 2 Kasihan Bantul. Populasi penelitian ini adalah seluruh peserta didik kelas VIII SMPN 2 Kasihan Bantul. Sampel penelitian ini adalah sebagian murid kelas VIII A, B, C, dan D. Sampel dipilih dengan teknik probability sampling menggunakan Proportionate Stratified Random Sampling. Pengumpulan data dilakukan dengan menggunakan penyebaran kuesioner. Instrument penelitian berjumlah 24 butir pernyataan. Teknik analisis data menggunakan teknik analisis deskriptif kuantitatif. Hasil analisis deskripsi menggunakan uji Correlation Pearson Product Moment dengan SPSS 20 tentang hubungan keterampilan mengajar guru terhadap minat belajar siswa

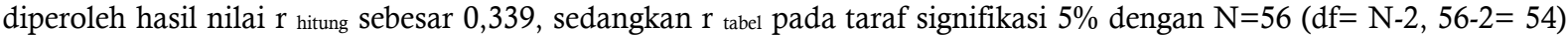
diperoleh hasil $r_{\text {tabel }}$ sebesar 0,2221. Hasil analisis tersebut diketahui nilai $r_{\text {hitung }}$ lebih besar daripada $r_{\text {tabel }}(0,339>0,2221)$ maka Ha diterima dan karena nilai $r$ hitung positif berarti hubungan juga positif, maka hasil penelitian menunjukkan adanya hubungan keterampilan mengajar guru PPKn terhadap minat belajar peserta didik pada mata pelajaran PPKn di SMP 2 Kasihan Bantul.
\end{abstract}

Kata kunci: keterampilan mengajar, mata pelajaran ppkn, minat belajar, peserta didik

\begin{abstract}
Teachers have a very important role in the learning process in schools. Therefore, teachers are required to have innovative and creative teaching skills in order to increase students' interest in learning. The purpose of this study was to describe the effect of teaching skills of PPKn subject teachers on students' learning interest at SMPN 2 Kasihan Bantul. This research is included in quantitative research. The success of this study was seen from the influence of the teaching skills of the PPKn subject teachers on the learning interest of students of SMPN 2 Kasihan Bantul. The population of this study were all students of class VIII SMPN 2 Kasihan Bantul. The sample of this research was some students of class VIII $A, B, C$, and D. The sample was selected by using probability sampling technique using Proportionate Stratified Random Sampling. Data collection was carried out using questionnaires. The research instrument consisted of 24 statement items. The data analysis technique used quantitative descriptive analysis techniques. The results of the descriptive analysis using the Pearson Product Moment Correlation test with SPSS 20 regarding the relationship of teacher teaching skills to student learning interest obtained the results of the $r$ count value of 0.339 , while the r table at the $5 \%$ significance level with $N=56(d f$ $=N-2,56-2=54)$ the r table results are 0.2221 . The results of the analysis show that the value of $r$ count is greater than $r$ table $(0.339 \mathrm{>}$ 0.2221), then Ha is accepted and because the value of $r$ count is positive, it means that the relationship is also positive, the results of the study show that there is a relationship between the teaching skills of PPKn teachers and the students' interest in learning in their eyes. PPKn lessons at SMP 2 Kasihan Bantul.
\end{abstract}

Keywords: teaching skills, ppkn subjects, interest in learning, students

Copyright (C2020 Universitas Ahmad Dahlan, All Right Reserved

\section{PENDAHULUAN}

Pembelajaran merupakan suatu faktor yang penting untuk meningkatkan kualitas pendidikan terutama di dalam sekolah maka dari itu guru dituntut untuk memiliki kemampuan mengajar atau sering disebut keterampilan mengajar yang bervariasi dan unik dalam mengelola suatu kelas supaya peserta didik dapat menerima materi tersebut dengan utuh serta tidak jenuh dalam proses pembelajaran di kelas dan dapat mempunyai ketertarikan pada materi yang diajarkan oleh guru.

Mengajar adalah suatu keharusan yang dilakukan oleh guru untuk memenuhi kewajibannya sebagai tenaga pendidik. Dalam melaksanakan tugasnya, guru harus melakukan kegiatan 
pembelajaran secara profesional dan memperhatikan segala hal yang berhubungan dengan pekerjaannya, seperti mempersiapkan materi pembelajaran dan perangkat pendukung untuk memudahkan guru dalam menyampaikan isi materi.

Keterampilan mengajar merupakan kebutuhan yang sangat penting dalam proses pembelajaran. Keterampilan mengajar mempunyai kaitan yang sangat kuat dengan minat belajar peserta didik seperti penelitian yang dilakukan oleh Saleh et al. (2017) menjelaskan bahwa keterampilan mengajar guru yang bervariasi dapat meningkatkan minat belajar peserta didik dibandingkan guru yang hanya menggunakan keterampilan mengajar yang monoton seperti metode ceramah tanpa menggunakan keterampilan mengajar yang lain. Penelitian yang hampir sama juga pernah dilakukan oleh Alwiyah \& Imaniyati (2018) mengatakan keterampilan mengajar dan kesiapan belajar peserta didik mempunyai keterkaitan yang sangat kuat dan dapat mempengaruhi hasil belajar peserta didik, keterampilan mengajar yang menarik dan kesiapan peserta didik dalam menerima materi pembelajaran akan menghasilkan prestasi bagi peserta didik.

Meningkatkan rasa minat belajar peserta didik membutuhkan keterampilan mengajar yang kreatif sehingga peserta didik mempunyai daya tarik terhadap mata pelajaran yang diajarkan oleh guru, guru juga harus selalu memperhatikan keadaan masing-masing individu dengan menggunakan metode pembelajaran yang bervariasi dan tidak hanya menggunakan gaya mengajar yang monoton saja seperti menggunakan metode ceramah yang membuat peserta didik merasa bosan di dalam kelas dan mengakibatkan materi yang diajarkan oleh guru tidak terserap oleh peserta didik.

Berdasarkan hasil magang terapan yang dilakukan oleh peneliti pada tahun 2017 di SMPN 2 Kasihan Bantul, pada umumnya guru belum memiliki keterampilan mengajar yang bervariasi. Adapun metode yang sering digunakan adalah metode ceramah. Perihal metode ini tampak belum melibatkan peserta didik dalam proses pembelajaran, oleh karena itu diperlukan sekali inovasi dan kreativitas dari bapak dan ibu guru, yakni dalam bidang keterampilan mengajar.

Penelitian ini dilakukan karena pada umumnya keterampilan mengajar guru dalam proses pembelajaran belum maksimal, masih banyak guru yang belum menguasai keterampilan mengajar contohnya saja ketika proses pembelajaran guru cenderung menggunakan keterampilan mengajar yang monoton seperti menggunakan metode ceramah saja tanpa menggunakan keterampilan mengajar yang lain, hal itu terbukti pada saat peneliti sedang menjalani magang di sekolah peneliti menemukan beberapa guru yang belum menggunakan delapan keterampilan mengajar dan hal tersebut mengakibatkan minat belajar peserta didik menjadi rendah, seharusnya guru dapat menguasai keterampilan mengajar yang kreatif serta inovatif supaya kelas menjadi tidak membosankan dan peserta didik menjadi betah di dalam kelas serta peserta didik memiliki minat dalam pembelajaran dan dapat meningkatkan prestasi. Oleh karena itu penelitian ini di-lakukan untuk mengetahui keterampilan mengajar yang baik dan dapat meningkatkan minat belajar peserta didik dalam segala jenjang pendidikan dan di dalam situasi pembelajaran apapun guru dapat menyesuaikan keterampilan mengajarnya yang inovatif.

\section{METODE PENELITIAN}

Penelitian ini menggunakan metode penelitian kuantitatif yang lebih menekankan kepada pengujian teori melalui angka-angka, dengan pengukuran variabel-variabel yang akan diteliti. Dengan kata lain metode penelitian kuantitatif pada dasarnya menggunakan suatu kerangka teori, gagasan para ahli, maupun pengalaman peneliti yang kemudian dikembangkan menjadi suatu permasalahan dan pemecahan untuk mencari kebenaran dengan menggunakan data empiris yang terdapat di lapangan (Sugiyono, 2017).

Peneliti menggunakan metode kuantitatif karena peneliti ingin mengetahui pengaruh yang timbul dari keterampilan mengajar guru terhadap minat belajar peserta didik dalam proses pembelajaran di kelas. Untuk mendapatkan data dalam penelitian ini menggunakan penelitian korelasional (corelational studies). Penelitian korelasional merupakan metode yang digunakan untuk mengetahui adakah hubungan antara kedua variabel menggunakan statistik analisis korelasi dan mengetahui seberapa besar hubungan antara kedua variabel yang kemudian dinyatakan dengan angka. Penelitian yang digunakan disesuaikan dengan tujuan peneliti yaitu untuk mengetahui pengaruh keterampilan mengajar guru terhadap minat belajar peserta didik. Kemudian hasil data yang diperoleh dapat dijelaskan berupa angkaangka untuk mengetahui pengaruh dari setiap variabel.

\section{HASIL DAN PEMBAHASAN}

Berdasarkan analisis data yang telah diperoleh dapat diketahui bahwa keterampilan 
mengajar guru yang berada pada rentang nilai tertinggi hingga terendah adalah yang pertama keterampilan memberikan penguatan sebesar 160 $(11,9 \%)$, kedua keterampilan bertanya sebesar 159 $(11,8 \%)$, ketiga keterampilan mengelola kelas sebesar $153(11,3 \%)$, keempat keterampilan menjelaskan sebesar 152 (11,3\%), kelima keterampilan menggunakan variasi sebesar 146 $(10,8 \%)$, keenam keterampilan membimbing diskusi kelompok kecil sebesar 142 (10,5\%), ketujuh keterampilan mengajar kelompok kecil dan perorangan sebesar 126 (9,3\%), dan kedelapan keterampilan membuka dan menutup pelajaran sebesar 124 (9,2\%). Keterampilan mengajar bagi guru ialah sesuatu yang sangat penting yang harus dimiliki oleh guru (Wahyulestari, 2018). Hal demikian karena guru adalah tenaga pendidik maka dari itu dalam proses pembelajaran di kelas guru dapat berperan sebagai motivator, fasilitator maupun orang tua bagi peserta didik (Zainal, 2010).

Data hasil analisis deskriptif variabel minat belajar peserta didik di SMPN 2 Kasihan Bantul juga dapat diketahui dengan rincian untuk kategori rendah sebesar $7,14 \%$, sedang $46,4 \%$, dan tinggi $46,4 \%$. Jadi dapat diketahui minat belajar peserta didik di SMPN 2 Kasihan Bantul termasuk dalam kategori tinggi dan sedang karena memiliki frekuensi yang sama. Melalui analisis skor indikator minat belajar, dapat diketahui bahwa indikator yang memiliki skor tertinggi hingga terendah adalah yang pertama perhatian peserta didik sebesar 130 (19,3\%), kedua perasaan senang sebesar 119 (17,7\%), ketiga keterlibatan peserta didik sebesar $101(15,0 \%)$, dan yang keempat 100 $(14,8)$. Peserta didik yang memiliki minat terhadap suatu pelajaran akan merasa senang dan mempunyai daya tarik terhadap apa saja yang berkaitan dengan pelajaran tersebut (Slameto, 2015). Peserta didik yang secara aktif membaca buku, mengerjakan tugas, dan mengulang kembali mempelajari mata pelajaran yang telah diajarkan oleh guru tersebut dapat disebut memiliki tingkat minat belajar yang cukup tinggi sehingga dapat mempunyai dampak yang positif. Hal ini tentunya sesuai dengan yang dijelaskan oleh Achru (2019), beberapa hal yang termasuk dalam unsur minat belajar adalah; perhatian, perasaan senang, dan motivasi. Adapun indikator untuk menentukan minat belajar seseorang dapat dilihat pada lima aspek yaitu: 1) rajin dalam belajar, 2) tekun dalam belajar, 3) rajin dalam mengerjakan tugas, 4) memiliki jadwal belajar, dan 5) disiplin dalam belajar.

Hasil analisis deskripsi yang dilakukan dengan menggunakan uji Correlation Pearson Product Moment dengan SPSS 20 tentang hubungan keterampilan mengajar guru terhadap minat belajar siswa diperoleh hasil nilai $\mathrm{r}$ hitung sebesar 0,339 , sedangkan $r$ tabel pada taraf signifikasi $5 \%$ dengan $\mathrm{N}=56(\mathrm{df}=\mathrm{N}-2,56-2=54)$ diperoleh hasil $r$ tabel sebesar 0,2221. Hasil analisis tersebut diketahui nilai $\mathrm{r}$ hitung lebih besar daripada $\mathrm{r}$ tabel $(0,339>0,2221)$ maka Ha diterima dan karena nilai $\mathrm{r}_{\text {hitung }}$ positif berarti hubungan juga positif, semakin tinggi keterampilan mengajar yang diberikan guru maka semakin tinggi pula minat belajar peserta. Berdasarkan analisis tersebut, dapat disimpulkan bahwa ada hubungan positif antara keterampilan mengajar guru dengan minat belajar peserta didik apabila diinterpretasikan besarnya koefisien korelasi 0,339 termasuk ke dalam kategori rendah karena berada pada rentang antara 0,200-0,399. Melalui penjabaran tersebut dapat diketahui bahwa ada hubungan keterampilan mengajar guru terhadap minat belajar siswa kelas VIII SMP N 2 Kasihan Bantul Tahun Ajaran 2018-2019.

Berdasarkan hasil pembahasan diatas, maka dapat diketahui bahwa keterampilan mengajar guru yang tinggi dan semakin bervariasi serta kreatif maka akan semakin tinggi untuk meningkatkan minat belajar peserta didik ataupun sebaliknya jika dalam hal mengajar tidak memiliki keterampilan mengajar yang kreatif maka peserta didik cenderung bosan serta tidak memperhatikan guru pada saat mengajar. Penelitian ini menjelaskan bahwa adanya hubungan keterampilan mengajar guru dengan minat belajar peserta didik di SMPN 2 Kasihan Bantul Yogyakarta berada dalam kategori rendah karena berdasarkan hasil uji korelasi yang dibantu SPSS 20 skor hanya mencapai 0,399 saja. Seperti halnya yang dijelaskan oleh Wibowo \& Farnisa (2018) bahwa 1) peningkatan prestasi belajar siswa dimulai dari diri siswa itu sendiri serta guru sebagai pendidik, sehingga guru harus berperan aktif dalam memotivasi belajar siswa agar memiliki prestasi belajar yang baik; 2) Guru lebih mampu membaca situasi kelas yang artinya metode pengajaran harus disesuaikan dengan suasana yang terjadi; dan 3) Pendekatan yang lebih intensif kepada siswa untuk menemukan kesulitan yang dihadapi oleh siswa.

Keterampilan mengajar yang bervariasi dan kreatif sangat perlu dimiliki guru untuk menciptakan pembelajaran yang menyenangkan (Hasma, 2017). Delapan indikator keterampilan mengajar yang dimiliki guru mata pelajaran PPKn di SMPN 2 Kasihan Bantul adalah sebagai berikut: Pertama keterampilan memberikan penguatan, guru memberikan perhatian lebih terhadap peserta didik dengan pendekatan yang dapat membuat peserta didik merasa nyaman. Kedua, keterampilan bertanya guru memberikan perhatian dan memfokuskan pelajaran kepada peserta didik yang membuat peserta didik merasa diperhatikan. Ketiga keterampilan mengelola kelas guru memberikan 
kenyamanan terhadap peserta didik dengan tidak membuat peserta didik menjadi tegang dan betah di dalam kelas. Keempat keterampilan menjelaskan guru dalam menyampaikan materi pelajaran menggunakan bahasa yang mudah di mengerti oleh peserta didik. Kelima keterampilan menggunakan variasi guru dalam menyampaikan materi pelajaran tidak monoton tetapi dapat menggunakan alat pendukung atau media sehingga materi tidak membosankan. Keenam keterampilan membimbing diskusi kelompok kecil guru membagi peserta didik menjadi bagian-bagian untuk saling bekerja sama dan berdiskusi mengenai materi. Ketujuh keterampilan mengajar kelompok kecil dan perorangan guru di lain membimbing diskusi kelompok guru juga dapat membimbing secara personal untuk membuat peserta didik semakin paham akan materi. Kedelapan keterampilan membuka dan menutup pelajaran guru mengawali pelajaran dengan menyapa peserta didik dan sedikit menyinggung materi sebelumnya serta menutup pelajaran dengan kesimpulan dan berdoa. Menurut Mansyur (2017) bahwa seorang guru memang harus mempunyai keterampilan dasar atau keterampilan minimal sebagai bagian dari profesi, sehingga pembelajaran akan sesuai dengan tujuan yang dikehendakinya.

Minat belajar peserta didik timbul dari keterampilan mengajar guru yang baik, minat belajar yang dimiliki oleh peserta didik ialah minat belajar berupa perasaan senang dan mempunyai ketertarikan atas suatu objek yang mempengaruhi kebiasaan seseorang (Slameto, 2015). Berdasarkan hasil analisis minat belajar peserta didik yang memiliki skor tertinggi ialah perhatian peserta didik sebesar 130 (19,3\%), perhatian peserta didik yang dimaksud adalah tingkat partisipasi peserta didik terbilang sangat aktif dalam pembelajaran sehingga dapat meningkatkan minat belajar peserta didik baik di dalam kelas maupun diluar kelas.

\section{KESIMPULAN}

Berdasarkan hasil penelitian dan pembahasan dapat disimpulkan bahwa terdapat hubungan positif antara keterampilan mengajar guru mata pelajaran PPKn dan minat belajar peseta didik di SMPN 2 Kasihan Bantul yaitu nilai $r$ hitung lebih besar daripada $r$ tabel $(0,339>0,2221)$ maka Ha diterima dan karena nilai $r$ hitung positif berarti hubungan juga positif, semakin tinggi keterampilan mengajar yang diberikan guru maka semakin tinggi pula minat belajar peserta.

\section{UCAPAN TERIMA KASIH}

Penulis menyampaikan terima kasih kepada semua pihak yang telah memberikan bantuan, arahan, dan motivasi selama penulis menyelesaikan penelitian ini. Kepada kedua orang tuaku, Bapak Yudah Upayadi dan Ibu I Dewa Ayu Diatri Nari Setyawati, terima kasih untuk do'a, cinta, kesabaran dan dukungannya dalam menyelesaikan studi ini, dan terima kasih untuk semua yang telah diberikan. Kakak tercinta Anindita Ayu Pradipta Yudah, Naomi Amelia Pradipta Yudah, dan adik tersayang Norman Audi Erlangga Pradipta Yudah, terima kasih atas dukungannya. Almamaterku Universitas Ahmad Dahlan, dosen pembimbing, serta teman-teman dan sahabat yang selalu mendampingi.

\section{DAFTAR PUSTAKA}

Achru, A. (2019). Pengembangan minat belajar dalam pembelajaran. Idaarah, 3(2), 205-215.

Alwiyah, D., \& Imaniyati, N. (2018). Keterampilan mengajar guru dan kesiapan belajar siswa sebagai determinan terhadap hasil belajar siswa. Manajerial, 17(1), 95-103.

Hasma, H. (2017). Keterampilan dasar guru untuk menciptakan suasana belajar yang menyenangkan. Didaktis: Jurnal Pendidikan dan Ilmu Pengetahuan, 17(1).

Mansyur. (2017). Keterampilan dasar mengajar dan penguasaan kompetensi guru (Suatu proses pembelajaran mikro). el-Ghiroh, 12(130-147).

Saleh, H. I., Danial, M., \& Junda, M. (2017). Hubungan antara Gaya Mengajar Guru dan Gaya Belajar Peserta Didik dengan Minat dan Hasil Belajar Biologi Peserta Didik SMA di Kota Bulukumba. UNM Journal of Biological Education, 1(1).

Slameto. (2015). Belajar dan Faktor-Faktor yang Mempengaruhi. Jakarta: Rineka Cipta.

Sugiyono. (2017). Metode Penelitian Bisnis: Pendekatan Kuantitatif, Kualitatif, Kombinasi, Dan R\&D. Bandung: CV. Alfabeta.

Wahyulestari, M. R. D. (2018). Ketrampilan Dasar Mengajar di Sekolah Dasar. Prosiding Seminar Nasional Pendidikan, 1(1).

Wibowo, I. S., \& Farnisa, R. (2018). Hubungan Peran Guru Dalam Proses Pembelajaran Terhadap Prestasi Belajar Siswa. Gentala Pendidikan Dasar, 3(2), 181-202.

Zainal, A. (2010). Micro Teaching. Jakarta: Raja Grafindo Persada. 
Jurnal Citizenship: Media Publikasi Pendidikan Pancasila dan Kewarganegaraan

Vol. 3, No. 2 Tahun 2019 | Hal. 53-56

e-ISSN: 2614-0039 